\title{
Syrian Refugee Crisis in Turkey: Is Migration from Syria Bad for Turkey's demographic and economic structure?
}

Ali Erdem Altun ( $\square$ alierdem.altun@nunokullari.com )

NUN Schools https://orcid.org/0000-0003-4538-3474

\section{Research Article}

Keywords: Refugee, Economy, Sociology, Turkey, Migration

Posted Date: November 30th, 2021

DOI: https://doi.org/10.21203/rs.3.rs-1110993/v1

License: (c) (i) This work is licensed under a Creative Commons Attribution 4.0 International License.

Read Full License 


\section{Abstract}

The main objective of this paper is to understand whether international migration is detrimental for the host country or not by using the example of Turkey. This paper primarily claims that refugees are beneficial for the host country Turkey as they stimulate the economy while integrating into the society they live in and taking the jobs that native people aren't enthusiastic about doing. As a result, they are easing the burden on the insurance system. From a demographical and a sociological perspective, they are increasing the rate of population in territories of Turkey where the fertility rate has declined. However, some economists and sociologists argue those claims with some counterarguments, which this paper is refuting. They claim that refugees have a terrible influence on Turkey's economy and the country's wellbeing by overburdening schools and healthcare facilities, boosting the crime rates, spreading disease, and heating the wage competition.

\section{Introduction}

There are more refugees in the world than there were in the post-World War II era, the UN Refugee Agency states.[1] In today's world, approximately 50 million people are displaced from their countries and forcefully migrated to other nations, whether legally or illegally. (Figure 1.) The concept of migration indicates the flow of people from their land, either across a global border or within a state.[2] Many scholars believe that the idea of migration is almost old as human history and dates back to the cradle of humanity.[3] However, due to the current climate of international relations, people make the most complex decisions of their lives to leave their country and their settled habitats at even more enormous rates.[4] Sociologists claim that there are diverse reasons why individuals immigrate, including war, climate change, lack of education, and financial conditions.[5] Still, in this paper, I will mainly focus on the effects of war on migration in the scope of Syrian refugees, and I will argue that these refugees are beneficial for the host countries by using the case study of Turkey. When the number of refugees in Turkey is considered, they could be regarded as a valuable aspect to the country. This is because they fulfill empty employee spots, and they are helping the healthcare system keep its costs at a fixed level along with many more benefits.[6]

In the first section of my article, I will explain the two common approaches towards refugees. One claims they are nothing but a burden on the economy and the country's well-being as they are stealing jobs from native people when finding jobs is already challenging and boosting crime rates. However, the other approach, which this paper emphasizes, claims they are beneficial for the host countries. They stimulate the economy while integrating into the society they live in and taking the jobs that native people aren't enthusiastic about doing rather than stealing. As a result, they are easing the burden on the insurance and healthcare system.

Moreover, from a demographical and sociological perspective, immigration increases the rate of population in countries where the fertility rate has declined.[7] While I'm emphasizing the claim that refugees are beneficial for the host countries throughout my essay, I will provide some evidence and data 
that push back the first claim. In the second section of my report, I will be placing those two approaches into the example of Turkey to try to deduce, on a further level, whether refugees are beneficial or detrimental for the host country. I will also address various strategies that the Turkish Government should follow in order to integrate the Syrian Refugees into the Turkish culture without assimilating any of the cultures to maximize those benefits. In conclusion, I will present my findings.

[1] The UN Refugee Agency, 2021a

[2] UN Migration, 2021a

[3] Mirjam Girsberger 2015. 1-12.

[4] Sorenson 2016

[5] Bodvarrson, Berg. 2013

[6] In this study, the only refugee group I'm referring to is Syrian refugees.

[7] Desiderio 2020

\section{The General Approaches Towards Refugees}

In March 2011, the idea of revolution and freedom in Syria quickly turned into a civil war, leading to an increment in the number of refugees worldwide.[1] Along with Syria, the chaos in the Middle East contributed to this increase immensely. While this increment in forceful displacement was taking place, Turkey promoted a liberal strategy of keeping its borders open for possible immigration throughout this humanitarian debate. With this open-door policy for the refugees on its border, Turkey became one of the countries that contain the most significant number of refugees. According to the latest studies, it is estimated that there are approximately 50 million refugees are present on a global scale, and 3.5 million of them are registered in Turkey.[2] Therefore, the distribution of refugees amongst cities in Turkey is ubiquitous and saturated. As visible from figure 2, Sanliurfa, Gaziantep, Hatay, and Istanbul are the cities that contain the greatest number of Syrian refugees.[3] While the immigrants initially remained in the border municipalities, they later turned towards the large cities and looked for jobs to make a living.

Many scholars, economists, and sociologists divide into two main views with respect to admitting refugees into the country. One widely accepted outlook perceives refugees as a threat to the country and claims they harm its overall well-being. A critical threat to a country contains two significant aspects in its structure: economic and physical danger.[4] Thus, for a community and state to feel threatened by refugees, these two factors need to be present. An economic threat indicates the perception of refugees as the primary source of financial instability. For example, one might think that the high unemployment rate in Turkey is related to refugees and that they contribute to the bankruptcy of the economy. On the other hand, the physical threat generally implies damage to the social structure and the social safety caused by the flow of refugees, such as the belief that they are increasing the crime rates. For example, according to a report released by UN Refugee Agency, a number of countries in Europe, including Greece, 
France, and some Scandinavian countries' concerns about refugees, have encouraged the growth of antiimmigrant parties.[5]

However, some scholars state the exact opposite, claiming refugees are stimulating the economy and are beneficial for the country rather than perceiving them as a threat.[6] Moreover, while refuting the claims that refugees are detrimental, these scholars deny that refugees increase crime rates or harm the economy. Now I will be explaining these two central outlooks in detail with continuous references to Turkey.

[1] Yıldııım, Şekerci 2020

[2] Toğral Koca. 2016.

[3] Duruel, 2017

[4] Topal, Özer, Dokuzlu 2017. 38

[5] UN Refugee Agency, 2021a

[6] Esen, Binatlı. 2017

\section{Perception Of Refugees As A Threat}

In Turkey, it is almost inevitable to talk about the unemployment rate when discussing the circumstances of Syrian refugees. This is because the perception of refugees stealing jobs from those who struggle to find one has a lot of supporters within the Turkish community-as visible from the graph by the World Bank (figure.3), obtaining a job in Turkey is arguably challenging. Thus, the unemployment rate increases in Turkey.[1] There are diverse reasons why the unemployment rate is this high in Turkey and inconsistent throughout the years. According to the conclusion of a study done by an economists who tried to identify the factors that affect Turkey's unemployment rate, "economic growth affects unemployment negatively in Turkey. This shows that the economic performance of the country should be improved to decrease the unemployment rate. Furthermore, interest rate positively influences unemployment rates. In other words, in the case of high-interest rates, investment levels are reduced, which causes a higher unemployment rate."[2] However, many people believe that the significant number of refugees flooding into Turkey is a factor that contributes to this increase.

The perception that refugees are responsible for Turkey's higher unemployment rate than it ought to be beget prejudice towards refugees. [3] The majority of the Turkish people, especially young generations, and small business owners, believe they cannot obtain jobs, or their jobs are at stake because of the dramatic increase in Syrian refugee numbers. Though the majority of economists disagree with this outlook, some of them still emphasize that refugees are contributing to the unemployment rate as they work for minimal amounts and without insurance. A paper put together by economists Salih Ozturk and Selen Çotlu claims that refugees contribute to overall poverty;[4] according to their reasoning, the fact that Turkey has spent a tremendous amount of money on refugees has overshadowed the poverty of the 
native people. Also, other papers in scholarly literature emphasize that those employers who choose to employ Syrian refugees rather than the native people negatively influence the economy and the country's overall well-being.

Additionally, there are some papers that address the negative influences of Afghan refugees on the social and economic growth of Pakistan and other countries in the Middle East. An article published in the International Migration Journal that approaches the context of the overflowing refugees from a financial perspective by using the ARDL bound test[5] concludes, " The estimated results yield evidence that Afghan refugees have a negative effect on the economic growth of Pakistan, in both the short and the long-run. The effects are highly significant with enough economic magnitude, especially in the long run. The study indicates that the traditional growth determinants such as human capital, investment and population growth are carrying their expected significance with desirable signs."[6] Even though the variables they use in these sorts of studies are not related to Turkey's contemporary position with Syrian refugees, and the context is not remotely similar as Turkey is a more developed country than Pakistan or many other Middle Eastern countries, they can incline the prejudice towards refugees in the scholarly literature of Turkey. They could help to build a negative image of refugees, which in all cases, contributes to the failure of the economy regardless of the country.

In addition, one other widely accepted opinion that contributes to the perception of refugees as a threat is the belief that they are increasing the crime rates during the period they have stayed in Turkey. Precisely because the media highlights individual refugee crimes, the bias towards refugees dramatically rises in the Turkish community.[7] The growth of hashtags on social media promoting anti-refugee sentiments in Turkey has sped over the past couple of years as native people feel threatened by refugees both economically and physically because of these factors.

Though there is a lack of scholarly resources to support the after-mentioned adverse claims regarding the situation of refugees in Turkey, there are politicians worldwide who oppose immigrants in public events and eventually increase the prejudice towards them and might cause them to be seen unfavorably. The far-right leader Marine Le Pen in France is an example in this regard. She stated in 2017, "I would decide on a moratorium on all legal immigration to stop this frenzy, this uncontrolled situation that is dragging us down".[8] One more example is from the Dutch parliament in 2015. Geer Wilders' opinion about refugees is that "Masses of young men in their twenties with beards singing Allahu Akbar across Europe. It's an invasion that threatens our prosperity, our security, our culture and identity."[9] It is visible from both of these comments that these politicians, and therefore the general public, perceive refugees as massive threats to the well-being of their country, their economy, and their cultural identity

[1] Akgündüz, Aldan, Bağır, Torun. 2019. 83-91

[2] Yüksel, Adalı 2017.

[3] Gençler, Ayhan. 2020. 114 
[4] Öztürk, Çoltu. 2018. 188-98

[5] A method that is used to test presence of the long run relationship between the variables

[6] Baloch, Shah, Noor Lacheheb 2017

[7] Akar, Erdoğdu. 2019

[8] $B B C, 18$ April 2017, A1

[9] Reuters, 10 September 2015, A1

\section{Refuting The Perception Of Refugees As A Threat}

While the number of refugees flooding into the country increases each and every day, it is favorable to approach them as a beneficial phenomenon that, in the long run, will positively impact the country's economy, demographic structure and help meet its various needs. In this section, I will discuss the benefits of having refugees in the country from multiple lenses while refuting the perception of refugees as a threat.

\section{Refugees as The Fulfilment of Unqualified Employee Segment}

According to multiple studies, the widely promoted idea that suggests refugees are stealing jobs or increasing the unemployment rate within Turkey is neither reliable nor valid. A study done by the central bank of Turkey and Turkish politician Nurettin Ceritoglu in early 2017 revealed that $18.8 \%$ of the refugees could not read or write. Also, $9.5 \%$ of them can read and write yet; they did not complete any level of education. $33 \%$ of them have only completed the elementary level of education. $19.4 \%$ of them completed middle school education. $9.6 \%$ of them completed pre-license education, and $9.7 \%$ completed education above bachelor level.[1] It is evident from these datasets that the refugees currently located in Turkey are not qualified enough for the jobs requiring further eligibility. Therefore, we can interpret this data as these refugees are fulfilling the need for unequipped employees to work in dirty works in Turkey. The term "dirty work" in refugee terminology refers to the exploitation of unauthorized immigrant populations. The refugees, mostly the unqualified ones, are seen as cheap labor in households, farms and stockyards, which are the jobs that do not require further education.[2] The studies about this issue reveal that refugees are generally working jobs that local people aren't diligent about taking. Table 1 shows the refugee numbers by job occupation and, in contrast, the number of Turkish people working at the same job.[3] 
Table 1: Number of Syrian Refugees by occupation [27]

\begin{tabular}{lccc} 
& \multicolumn{2}{c}{ Syrian refugees } & Informal Turkish workers \\
Occupation (ISCO code) & Total & Share & Share \\
\hline \hline Labourers in manufac. and construc. (93) & 137,210 & 16.9 & 6.9 \\
Stationary plant and machine opera. (81) & 131,305 & 16.1 & 2.7 \\
Woodworking and garment workers (75) & 105,123 & 12.9 & 4.9 \\
Sales workers (52) & 61,194 & 7.5 & 15.5 \\
Building and related trades workers (71) & 57,440 & 7.1 & 7.5 \\
Agricultural labourers (92) & 56,429 & 6.9 & 5.8 \\
Metal, machinery workers (72) & 38,741 & 4.8 & 2.9 \\
Personal services (51) & 35,281 & 4.3 & 4.3 \\
Cleaners, helpers (91) & 35,000 & 4.3 & 4.4 \\
Other occupations & 156,058 & 19.2 & 42.1 \\
\hline Total & 813,781 & 100.0 & 100.0 \\
\hline
\end{tabular}

Among these occupations, laborers and constructers, stationery plants, and machine operators are abundant in Syrian refugees. In contrast, the share of Turkish people doing the same jobs is relatively minor. Researches state that the native people do not want to perform these occupations, and refugees are the only workforce to fulfil this employee segment.[4] In other words, refugees are not stealing jobs but instead taking the jobs that no one else is willing to take. The same studies also indicated that the only affected group from this increasing unqualified workforce of Syrians is native unskilled workers, which means a small group who have not received a certain level of education. [18] Yet, this does not directly affect the unemployment rate. [26] Most employers choose to employ refugees rather than native workers because hiring a native requires paying for their insurance and providing them with a safe environment. Since most employers exploit refugees as cheap labor, they do not provide them with a proper work environment. Due to the lack of qualification, refugees are obligated to do any job to earn a living, though studies show that most people who die in work accidents are refugees.[5]

\section{Economic and Demographic Aspects of Having Refugees}

Selen Çotlu, and Salih Ozturk, Turkish economists, state, "it is unlikely that the Syrian refugee flood, which has a negative impact on the country's development, will be resolved in the near future." [19] In their thesis, they emphasize the negative aspects of the flood of refugees and claim that the flow of refugees is vitally hurting the economy. However, when we look at data, we can see that in 2017, Turkey's economy 
grew 7.4\%.[6] According to the acclaimed economist Ercan Erguzel, Syrian refugees located in the country since 2011 have contributed immensely to this growth for a couple of reasons. The most crucial is that the Turkish companies provide their day-to-day needs, which eventually contributes remarkably to the economy. [24] Furthermore, according to a report by the Turkish Economic and Social Studies Foundation, the Syrian refugees living in refugee camps also have a significant impact on the economy as the national economy provides for their needs. Yet again, according to this release, the textile and nutrition market are the ones that benefit most from the presence of the Syrian refugees in the country.[7] The IMF stated by looking at the cases of Germany and Australia, where the integration of refugees was successful, which led them to map a positive growth in their economies,[8] "immigration can bring substantial benefits to advanced economies, in terms of higher per capita GDP and standards of living. These gains are broadly shared by the population. But the key to reaping these benefits is to address the challenges posed by migration in the short term and, in particular, to ensure that migrants are integrated into the labor market."[9]

As of 2017, studies indicated that there are 940,921 Syrian workers in Turkey [8]. By being involved in the work cycle and being present in the country, refugees are actually easing the burden on the insurance and healthcare system. Turkstat stated that the aging population in Turkey increased by $22.5 \%$ over the past five years, boosting the number of older people in Turkey to approximately 8 million.[10] As the nation ages, the dependence on health insurance also increases. However, currently, the average refugee age located in Turkey is 23.0 years old. (Figure 4)

Therefore, we can say that this creates a balance within the nation. The senior population is increasing; this drives higher health care expenses as they are more dependent. However, with this refugee flow, the burden on the healthcare system eases, and the costs can be kept at a fixed level. Similarly, the abundance of younger generations means an increased workforce and the capacity to develop the country. According to the Social Security Agency of Turkey, as of 2020, it is estimated that 1.80 people ought to be actively working to provide one's pension.[11] Therefore the increase in the workforce also eases the burden on the insurance system. [25]

\section{Decrease in Crime Rates: Presence of Refugees}

The debate of whether Syrian immigrants impact crime rates has been an ongoing conversation. In Figure 5, Turkey's crime rate from 2004 to 2018 is visible. Within this period of time, the crime rates have been unstable and vary a lot. However, it is visible that after 2011 the crime rate notably increased but dramatically decreased between 2012 to 2015. This time coincided with the influx of Syrian refugees to Turkey. So, after interpreting the table, we can say that the crime rate has decreased after refugees arrived in the country. When it comes to discussing the crime rates in the context of the flow of refugees into a particular country, it is possible to encounter two main arguments. The first one states that since there is an expansion in population due to refugees coming into the country, the number of people who could potentially commit a crime also increases. However, the other primary argument in this issue states the exact opposite: claiming that having refugees in the country could reduce crime rates since the central 
authority will take more strict precautions towards the possibility of someone committing a crime when there is an inflow of people into the country. Therefore, this view suggests that the central authority will suppress crimes at a substantial rate among the refugees and native people.[12] This phenomenon reveals that Syrian refugees actually do not increase the crime rates, and those who say the contrary have no evidence to support their claim. The paper named Do Refugees Cause Crime? by Aysegul Kayaoglu, an academic from the economics department in Istanbul Technical University, discusses this exact phenomenon. Based on this study published in a journal put together by Economic Research Forum, that paper concludes that "crime rates did not increase after refugee inflows, irrespective of their size," after approaching the refugee problem from various lenses. [37]

[1] illgazi. 2019

[2] Vogt 2020. 51-63

[3] Pinedo Caro 2020

[4] Ertekin, Sumeyye 2020

[5] Akyıldız, Ekmekçi, Başııil 2020

[6] Dogruluk Payı, 2021a

[7] Tesev, 2021a

[8] Thompson, Wissink 2019

[9] IMF, 2021a

[10] Anadolu Agency 2021a

[11] Social Security Agency, 2021a

[12] Kayaoglu, 2021. 8-13

\section{Future Paths To Follow}

Refugees currently residing in Turkey will likely be staying here for the foreseeable future as the situation in Syria is not getting any better. So, the Turkish Government should follow a more rational path in light of this massive number of refugees in the country. However, I have listed numerous benefits of having refugees in the country, such as their positive influence on the economy as they can be considered as additional workforces or the fact that they are easing the burden on the insurance and healthcare system if these benefits are put into context and in a more straightforward approach, those advantages would expand enormously.

The first obstacle that the Turkish Government should overcome is the cultural clash between the Turkish people and Syrian refugees; though both cultures resemble each other in some ways, the Turkish Government should still come up with a pattern to integrate these refugees into the Turkish culture without assimilating them. For example, spreading awareness about refugees and breaking the stigma 
towards them should be the Government's priority so the public can acknowledge the arguable benefits of refugees. Language barriers between the Syrians and Turkish people are also contributing to this cultural clash immensely. This language barrier not only creates a sense of threat but also contributes to the negative image of Syrian refugees. Through workshops solely meant to emphasize refugee integration, teaching them Turkish would be an alternative. Another major problem with blending Syrian refugees into the Turkish culture is the lack of education and qualification. This paper has stated how the Turkish community benefits from Syrian refugees as they are fulfilling the need for unqualified employees. However, they also need to be able to access education so that Turkey could benefit from them in the future as Turkey also needs qualified employees in its structure. Though the Turkish Government should proceed to follow its liberal agenda of keeping its borders open, the tracking and registration of Syrian refugees into the country should be more systematic and precise to prevent any disorder that could emerge. [26] Also, in future terms, the Government should consider giving some refugees citizenship because, in this way, the ones who become citizens would be obligated to pay taxes, which eventually contribute to the economy in a significant way when the massiveness of the pool of Syrian refugees is considered. DIW Berlin's head of education and family, Katharina Spiess, stated, "The studies show that the integration of refugees has been successful in many areas," therefore, Germany could be perceived as an example of successful refugee integration. In Germany, refugees are seen as a way to address the country's labour shortage. Germany benefits from refugees in a more systematic way as they acknowledge the possible benefits they provide.[1]

[1] S. Trines 2021

\section{Conclusion}

In this paper, I have investigated the question, "Is International Migration Bad for Host Countries?" in the scope of the massive Syrian refugee numbers in Turkey. Based on my research, I found that Syrian refugees are beneficial for Turkey for various reasons. While I emphasized the benefits of refugees, I also refuted the opposing prejudicious claims from politicians, economists, and the general public. First, I started by describing how refugees are perceived as a threat within the Turkish community and listed the factors and comments contributing to that perception. Then, I explained the claims towards refugees, such as stealing jobs from the native Turkish people, increasing crime rates, etc. In the second section of my essay, I explained the benefits of refugees from several approaches, and through my writing, I supported my claims with datasets and graphs.

As an outcome of this research, it is visible that the Turkish community and state are benefiting from Syrian refugees. The current average refugee age is 23 , meaning they are preventing the ageing of the nation and reducing the dependency on the pharmaceutical industry, therefore, easing the burden and intensity on the healthcare system. They are also considered to be additional workforces. Currently, in Turkey, 1.80 people need to be actively working to provide one's pension. With the increasing refugee number, this number will gradually decrease. Also, if Turkey gave refugees citizenship, they would 
contribute to the economy differently as they would be obligated to pay taxes and provide for the country's well-being.

Those who state otherwise of what this thesis features and claim refugees are harmful to the well-being of the country and its economy are only speaking hypothetically. In fact, there is arguably almost no data or research to support their claims. Though this paper mainly focused on forceful immigration and discussed the Syrian refugees' potential benefits to the country, a lot of further questions can be raised after this research. For example, one might study willing immigration and, by citing some real-life examples from the world, answer the question of how states benefit from these people. Though there are limited sources in scholarly literature to support the idea that refugees are detrimental, the work that emphasizes their benefits is also not very abundant. Turkish scholars need to lean on this area more as extensive research on this topic is vital.

\section{References}

1. United Nations High Commissioner for Refugees. (n.d.). World Refugee Day: Global forced displacement tops 50 million for first time in post-World War II era. UNHCR. Retrieved September 16, 2021, from https://www.unhcr.org/news/latest/2014/6/53a155bc6/world-refugee-day-global-forceddisplacement-tops-50-million-first-time.html

2. 2021a. Key Migration Terms. Available from < https://www.iom.int/key-migration-terms> Accessed 03 August 2021.

3. Mirjam Girsberger, Esther. 2015. Essays on Migration, Education and Work Opportunities. 1-116 Ph.D. diss., European University Institute. Florence, Italy.

4. Sorenson, David 2016. Syria In Ruins. Santa Barbara, California: Prager Security International

5. Bodvarsson Ö.B., Van den Berg H. 2013. Why People Immigrate: The Evidence. In: The Economics of Immigration. Springer, New York, NY.

6. Desiderio, Rene. 2020 The Impact of International Migration on Fertility: An Empirical Study

7. Aydın Yıldırım, T., \& Gümüş Şekerci, Y. 2020. A door opening from Syria to Turkey; migration and the process of social acceptance and accommodation: Hatay and Karabuk provinces. International Social Work.

8. Toğral Koca, Burcu. 2016. Syrian refugees in Turkey: From "guests" to "enemies"?. New Perspectives on Turkey.

9. Duruel, Mehmet 2017. The Effects Syrian Refuges On The Turkish Labor Market: Opportunities And Threats. Uluslarası Ekonomi Araştırmaları Dergisi 3 (2) 208-222

10. 2021a. UNHCR Turkey: Provincial Breakdown Syrian Refugees in Turkey as of 8 January 2021, Available from <https://reliefweb.int/map/turkey/unhcr-turkey-provincial-breakdown-syrianrefugees-turkey-8-january-2021> Accessed 16 August 2021.

11. Topal, Özer, Dokuzlu 2017. Public perception of Syrian refugees in Turkey: an empirical explanation using extended integrative threat theory. 36-58 
12. Esen, Binatlı 2017. The Impact of Syrian Refugees on the Turkish Economy: Regional Labour Market Effects. 1-12

13. Akgündüz, Aldan, Bağır, Torun. 2019. 83-91 Job mobility in Turkey. Research and Monetary Policy Department, Central Bank of the Republic of Turkey, 19(3), 83-91.

14. Statista. (2021, July 20). The unemployment rate in Turkey 2020. https://www.statista.com/statistics/263708/unemployment-rate-in-turkey/

15. Gençler, Ayhan (2020). Türkiye'deki Suriyeli Sığınmacıların Sosyo-Ekonomik Yaşama Etkileri: Fayda Maliyet Ekseninde Bir Bakış. Sosyal Siyaset Konferansları Dergisi/Journal of Social Policy Conferences, 111-145.

16. Öztürk, Çoltu. 2018. The Effects Of Syrian Refugees On Turkish Economy. 188-98

17. Akar, Erdoğdu. 2019. Syrian Refugees in Turkey and Integration Problem Ahead.

18. BBC News. (2017, April 18). French election: Le Pen pledges to suspend immigration. https://www.bbc.com/news/world-europe-39625509

19. Staff, R. (2015, September 10). Wilders tells Dutch parliament refugee crisis is 'slamic invasion.' U.S. https://www.reuters.com/article/idUS250885087920150910

20. İlgazi, Aziz 2019. "Suriyeli Sığınmacıların Emek Piyasasına Etkileri Gaziantep ve Şanlıurfa Örneği". Econharran 3 (2019): 93-123

21. Vogt, Wendy 2020. Dirty Work, Dangerous Others. Migration and Society, 3(1), 50-63.

22. Pinedo Caro, Luis 2020. Syrian Refugees in the Turkish Labour Market: A Socio-Economic Analysis. Sosyoekonomi, 51-74.

23. Akyildiz, C., Ekmekci, S., \& Başligil, H. 2020. Göçmen İşçilerin isG Faktörlerinin İncelenmesi, Sonuçlar Üzerinde Tartışma ve Öneriler: Kapsam Belirleme Derlemesi. Gazi Journal of Engineering Sciences, 6(2), 145-159.

24. ÜçKuyu, M. K Suriyeli Sığınmacıların Türkiye Ekonomisine Etkileri. Doğruluk Payı. Retrieved August 16, 2021,

25. 2021a. Suriyeli Sığınmacıların Türkiye'ye etkileri. Available from < https://www.tesev.org.tr/wpcontent/uploads/rapor_Suriyeli_Siginmacilarin_Turkiyeye_Etkileri.pd f>Accessed 12 August 2021.

26. Thompson, Wissink 2019 Syrian Refugees May Hold the Key to Turkey's Economic Development and Geo-Political Ambitions

27. I. (2016, October 24). Migrants Bring Economic Benefits for Advanced Economies. IMF Blog. https://blogs.imf.org/2016/10/24/migrants-bring-economic-benefits-for-advanced-economies/

28. Turkey's elderly population rises to nearly 8 M in 2020. Anadolu Agency. Retrieved August 16, 2021, from https://www.aa.com.tr/en/turkey/turkeys-elderly-population-rises-to-nearly-8m-in2020/2180060

29. Main Page. (n.d.). Social Security Agency. Retrieved August 16, 2021

30. Turkey Crime Rate \& Statistics 2003-2021. (n.d.). MacroTrends. Retrieved August 16, 2021, from https://www.macrotrends.net/countries/TUR/turkey/crime-rate-statistics 
31. Ilgit, Asli, and Audie Klotz. "Refugee Rights or Refugees as Threats? Germany's New Asylum Policy." The British Journal of Politics and International Relations, vol. 20, no. 3, Aug. 2018, pp. 613631,

32. Aydin, H., Gundogdu, M. \& Akgul, A. Integration of Syrian Refugees in Turkey: Understanding the Educators' Perception. Int. Migration \& Integration20, 1029-1040 (2019).

33. Kayaoglu, Aysegul 2021. Do Refugees Cause Crime? Economic Research Forum Working Papers (No. 1470).

34. Nikos Christofis, Bahar Baser, Ahmet Erdi Öztürk. (2019) The View from Next Door: Greek-Turkish Relations after the Coup Attempt in Turkey. The International Spectator 54:2, pages 67-86.

35. Ertekin, S. (2020, March 10). Suriyeliler işimizi elimizden mi alıyor? Fikir Turu. https://fikirturu.com/ekonomi/suriyeliler-isimizi-elimizden-mi-aliyor/

36. Trines, S. (2021, July 23). The State of Refugee Integration in Germany in 2019. WENR. https://wenr.wes.org/2019/08/the-state-of-refugee-integration-in-germany-in-2019

37. Separate reports find that the integration of migrants in Germany is proceeding "well." (2020, August 21). InfoMigrants. https://www.infomigrants.net/en/post/26777/separate-reports-find-that-theintegration-of-migrants-in-germany-is-proceeding-well

38. Baloch, A., Shah, S. Z., Noor, Z. M., \& Lacheheb, M. (2017). The Economic Effect of Refugee Crises on Neighbouring Host Countries: Empirical Evidence from Pakistan. International Migration, 55(6), 90106. https://doi.org/10.1111/imig.12389

39. What is ARDL Bounds Testing / IGI Global. (n.d.). -. Retrieved September 15, 2021, from https://www.igi-global.com/dictionary/ardl-bounds-testing/47420

\section{Declarations}

\section{Conflict of Interest}

The author has no conflict of interest

\section{Figures}




\section{Global forced displacement | 1993-2013 (end-year)}

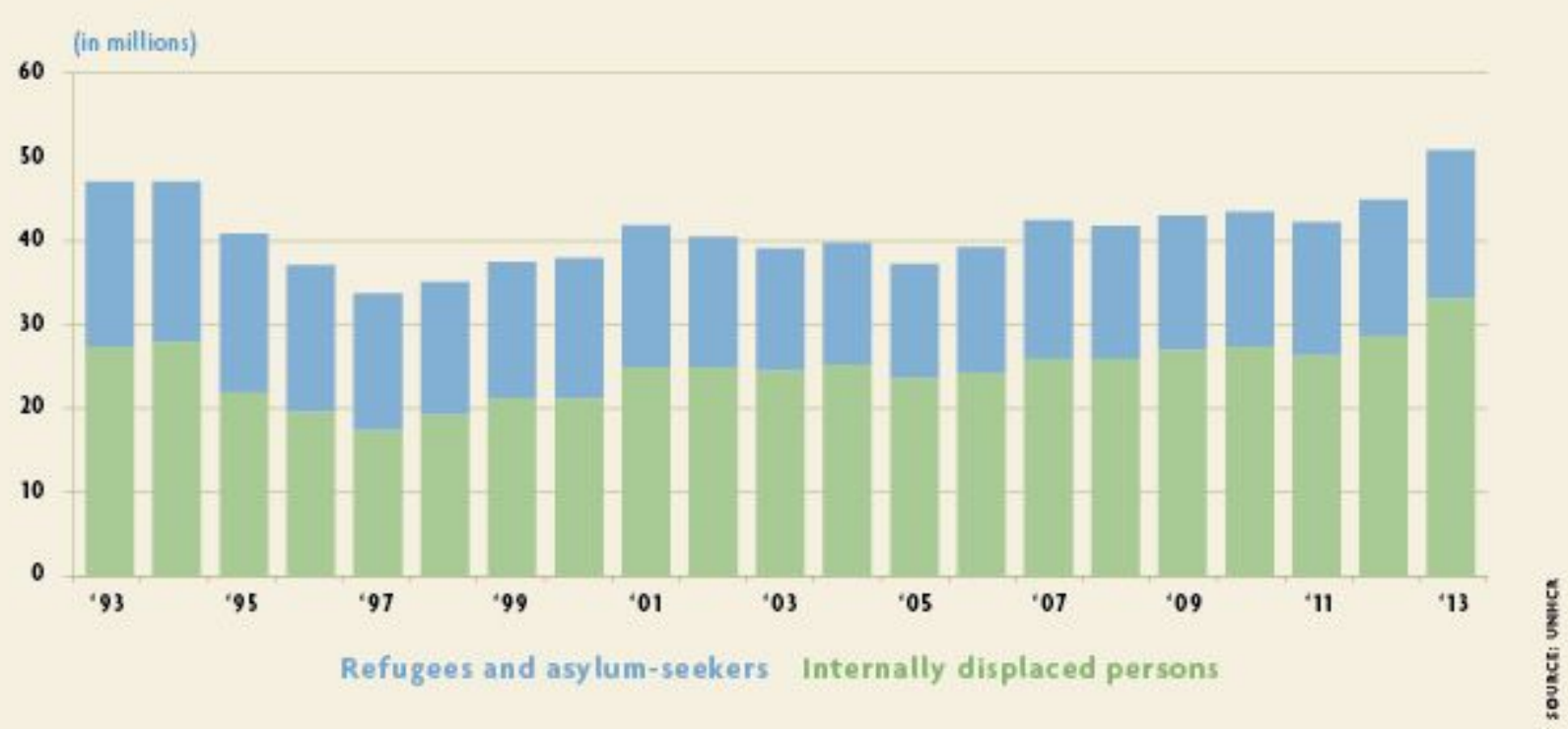

\section{Figure 1}

Global Forced Displacement (1993-2013) [1]

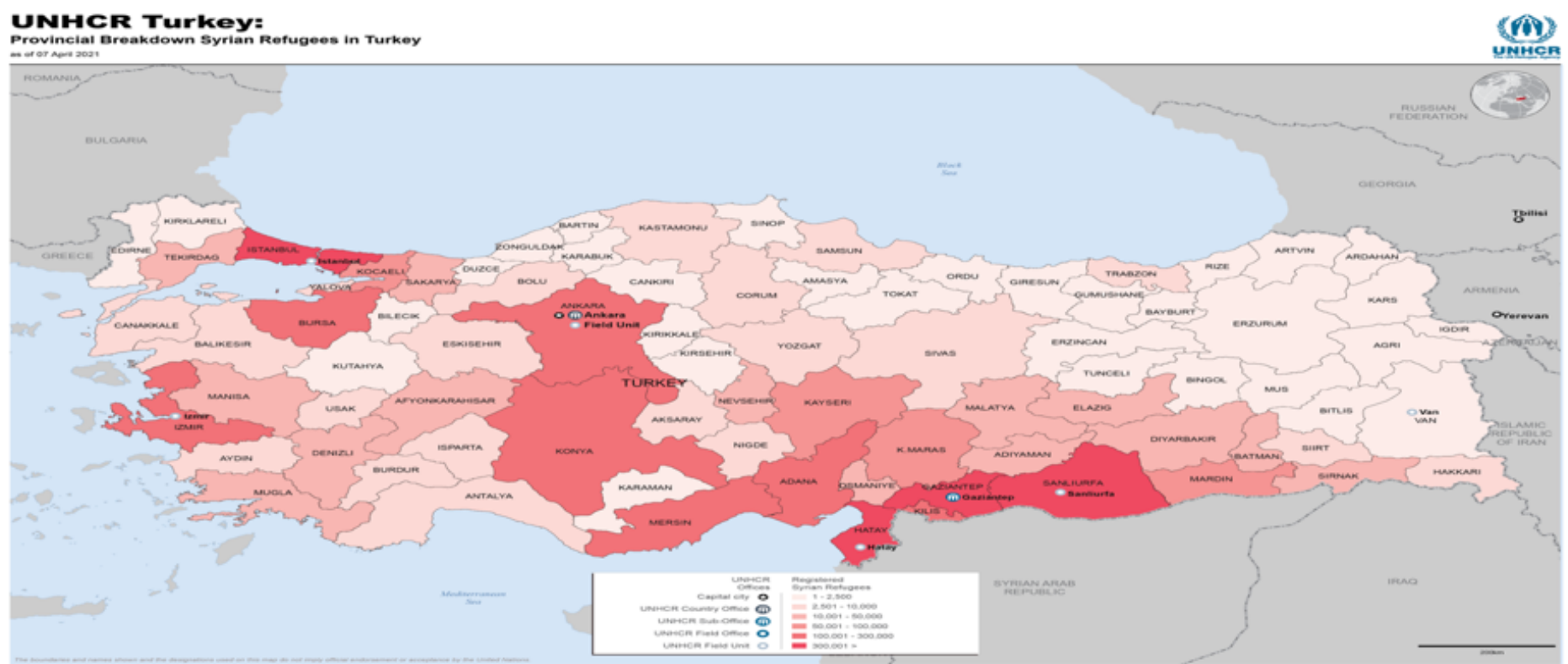

Figure 2

Provincial Breakdown of Syrian Refugees in Turkey 11 
Turkey: Unemployment rate from 1999 to 2020

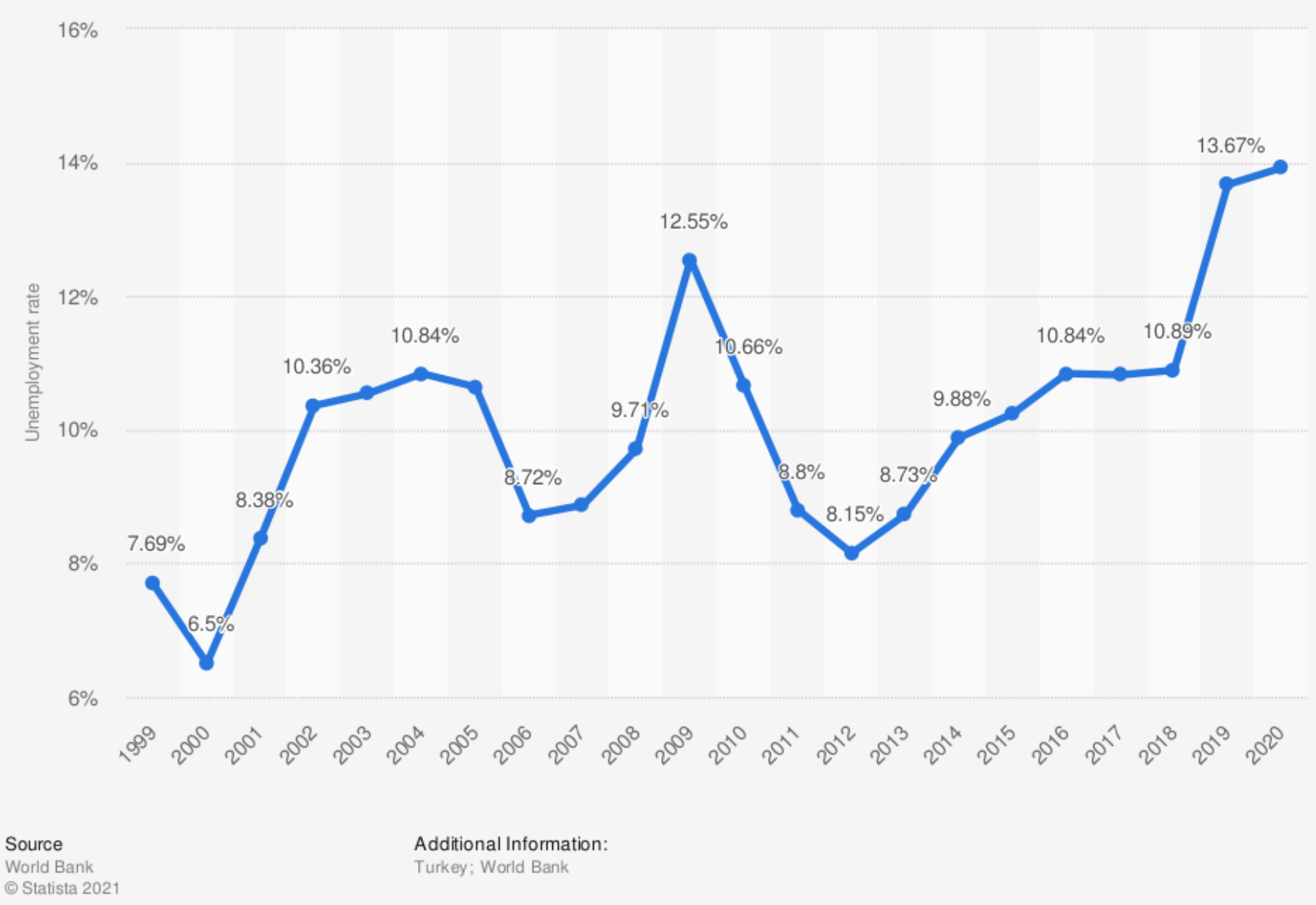

Figure 3

Turkey Unemployment Rate from 1999 to 202017

Page 15/16 


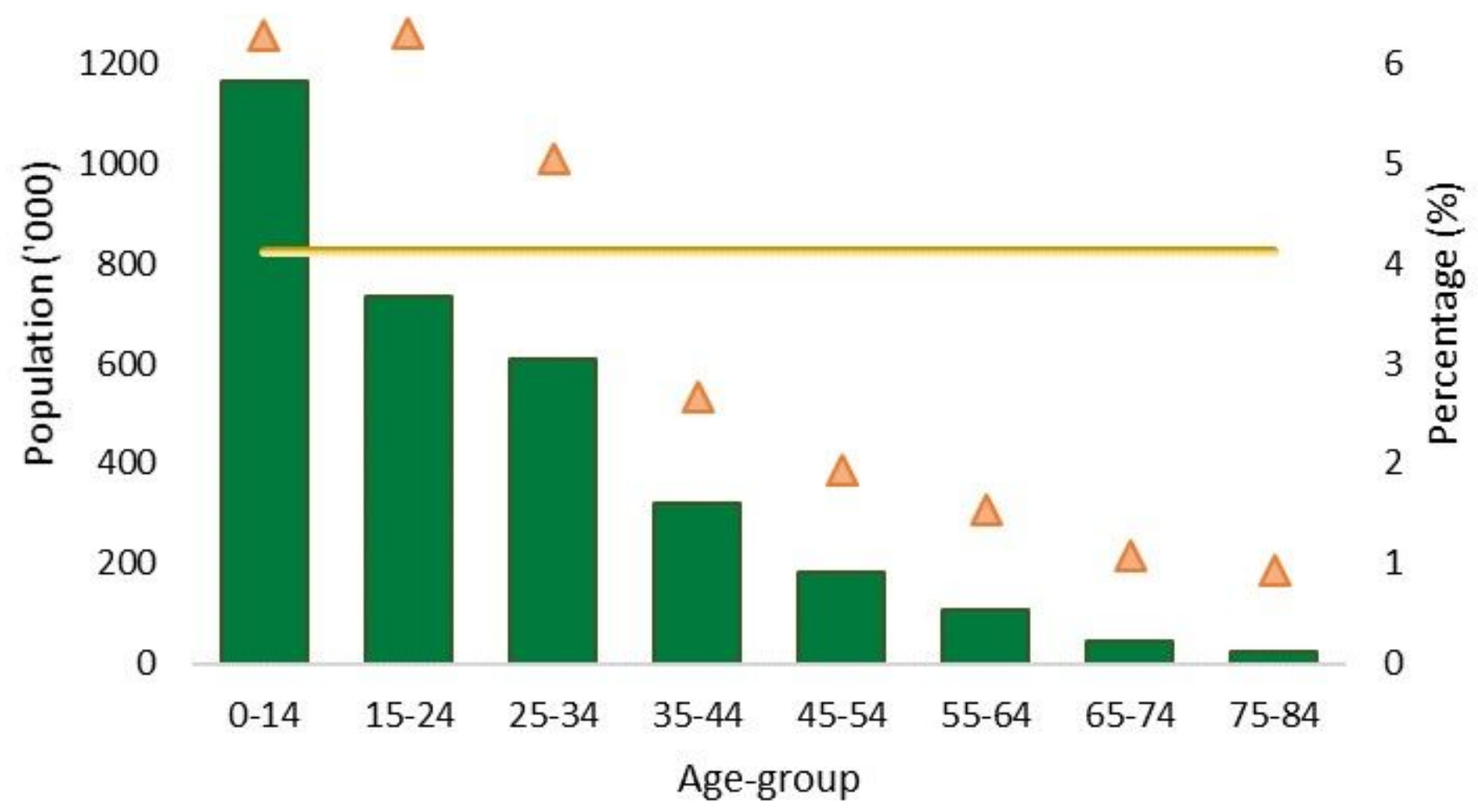

Figure 4

Syrian Refugee population, age distribution [25]

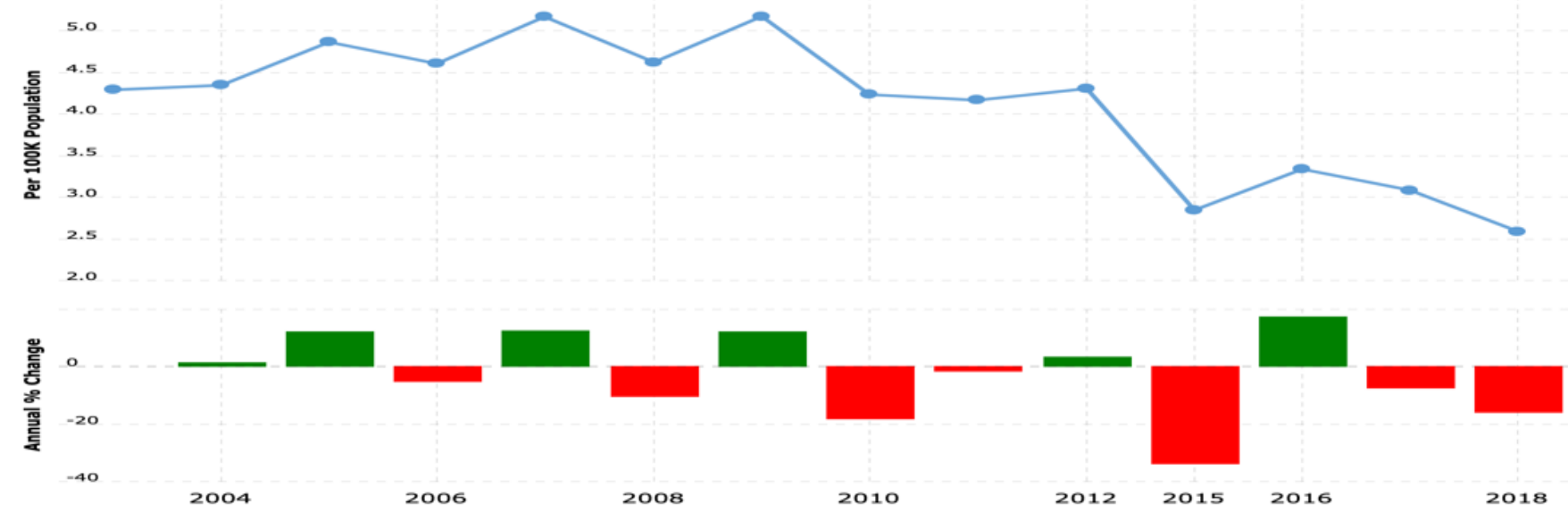

Figure 5

Turkey crime rates \& Statistics 2004-2018 37 